\title{
Uji Aktivitas Antiplatelet, Antikoagulan, dan Trombolitik Alkaloid Total Daun Pepaya (Carica papaya L.) secara in Vitro
}

(Antiplatelet, anticoagulant, and thrombolytic cctivities of total alkaloid extract of papaya leaves (Carica papaya L.) in Vitro)

\author{
Martina Kurnia Rohmah* \& Djelang Zainuddin Fickri \\ Program Studi S1 Farmasi STIKES Rumah Sakit Anwar Medika Jalan Bypass Krian, Jl. Parengan, \\ Semawut, Balongbendo, Kec. BalongBendo, Kabupaten Sidoarjo, Jawa Timur
}

\begin{abstract}
Papaya leaves have a number of alkaloid compounds (carpaine, pseudocarpaine, dehydrocarpaine I, dehydrocarpaine II, and emetine). This study aimed to determine the antiplatelet, anticoagulant, and thrombolytic activities of total alkaloids of papaya leaves in vitro. This study was divided into 5 groups: negative control, positive control, and total alkaloids of papaya leaves $(0.5,1.0$, and $2.0 \mathrm{mg} / \mathrm{mL})$ with 5 parameters: \% platelet aggregation inhibition, CT, PT, APTT, and \% thrombolytic. Based on statistical analysis, there was a significant difference between percentage of aggregation inhibition of total alkaloids and negative controls, but was not different with positive control (clopidogrel). Anticoagulant test showed that total alkaloid of papaya leaves significantly extended CT, PT, and APTT values compared with negative control, but was not significantly different with positive control (heparin). Thrombolytic test showed that total alkaloid of papaya leaves increased trombolitic percentage and significantly different from the negative control, but was not significantly different from positive control (nattokinase).
\end{abstract}

Keywords: Carica papaya; papaya; akaloid; antiplatelet; anticoagulant; thrombolytic.

ABSTRAK: Daun pepaya memiliki kandungan beberapa senyawa alkaloid (karpain, pseudokarpain, dehydrokarpain I, dehydrokarpain II, dan emetin). Penelitian ini bertujuan untuk mengetahui aktivitas antiplatelet, antikoagulan, dan trombolitik alkaloid total daun pepaya secara in vitro. Penelitian ini terdiri dari 5 perlakuan: kontrol negatif, kontrol positif, alkaloid total daun pepaya (konsentrasi 0.5, 1.0, dan $2.0 \mathrm{mg} / \mathrm{mL}$ ) dengan parameter persentasi inhibisi agregasi, persentase inhibisi koagulasi dari nilai Clotting Time (CT), Prothrombine Time (PT), dan Activated Parsial Thromboplastine Time (APTT), dan daya fibrinolitik. Berdasarkan analisis statistik diketahui bahwa terdapat perbedaan yang signifikan antara persentase inhibisi agregasi alkaloid total dibanding kontrol negative, namun tidak berbeda dengan kontrol positif (clopidogrel). Pada uji antikoagulan, alkaloid total daun pepaya secara signifikan dapat memperpanjang CT, PT, dan APTT yang berbeda signifikan dengan kontrol negatif, namun tidak berbeda dengan kontrol positif (heparin). Hasil uji trombolitik menunjukkan bahwa alkaloid total daun pepaya dapat meningkatkan persentase trombolitik yang berbeda dengan kontrol negatif, namun tidak berbeda signifikan dengan kontrol positif (nattokinase).

Kata kunci: Carica papaya; pepaya; alkaloid; antiplatelet; antikoagulan; trombolitik.

\section{Pendahuluan}

Kejadian aterotrombotik seperti infark miokard dan stroke iskemik merupakan penyebab utama morbiditas dan mortalitas akibat penyakit kardiovaskular di seluruh dunia dengan angka kematian 17,9 juta setiap tahun (31\%) [1]. Data Riset Kesehatan Dasar (Riskesdas) tahun 2018 menyebutkan bahwa angka kejadian penyakit jantung di Indonesia adalah 2,78 juta jiwa atau 15 dari 1000 orang [2]. Tingginya angka morbiditas dan mortalitas penyakit kardiovaskular ini memerlukan perhatian khusus melalui pengembangan terapi yang efektif.

Mekanisme yang mendasari kejadian aterotrombotik terdiri dari gangguan plak dan pembentukan sumbatan (trombus). Berdasarkan mekanisme patofisiologinya, trombus arteri terdiri dari agregasi trombosit sebagai akibat dari tingginya kecepatan aliran darah. Selain agregasi trombosit, peningkatan aktivitas faktor pembekuan dan kadar fibrin juga dapat memicu pembentukan trombus. Peningkatan aktivitas faktor pembekuan darah dan kadar fibrin disebabkan oleh peningkatan aktivitas faktor jaringan (tissue factor) yang meningkatkan aktivitas kaskade

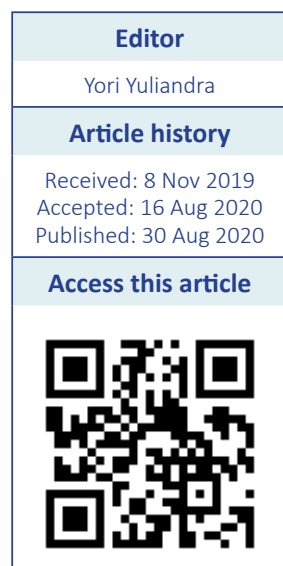


Tabel 1. Hasil uji fitokimia ekstrak alkaloid total daun pepaya

\begin{tabular}{cccc}
\hline & Uji Fitokimia & & \multicolumn{2}{c}{ Ekstrak Alkaloid Total Daun Pepaya } \\
\hline Golongan & Pereaksi & Fraksi Etanol & Fraksi Klorofom \\
\hline Alkaloid & Mayer & + & + \\
& Wagner & + & + \\
& Drugendorff & + & + \\
Flavonoid & & + & - \\
Saponin & & + & - \\
Tanin & & + & - \\
\hline
\end{tabular}

koagulasi (coagulation cascade). Selain itu, munculnya trombus juga dapat disebabkan oleh gangguan fibrinolitik yang mengakibatkan trombus tidak dapat mengalami lisis. Selain menutupi lumen vaskuler, trombus juga dapat menyebar melalui aliran darah hingga mencapai jantung. Kondisi aterotrombotik ini menyebabkan terjadinya pecah pembuluh darah (strok iskemia) dan nekrosis jaringan miokardium karena minimnya suplai oksigen dan berakibat pada infak miokard [3].

Pengendalian proses koagulasi yang baik dapat menurunkan potensi tingginya trombus pada kasus athreotrombotik. Obat anti pembekuan darah seperti antiplatelet, antikoagulan dan trombolitik digunakan untuk menurunkan aktivitas pembekuan darah untuk mencegah terbentuknya trombus maupun menghancurkan trombus agar aterotrombotik tidak terjadi. Namun demikian, sejumlah obat anti pembekuan darah memiliki efek samping yang cukup mengganggu. Aspirin dan klopidogrel sebagai antiplatelet memiliki efek samping berupa sakit kepala, kram perut, muntah dan ulserasi lambung [4-6]. Heparin sebagai antikoagulan memiliki efek samping di antaranya menyebabkan perdarahan, osteoporosis, dan trombositopenia [7]. Nattokinase sebagai agen trombolitik memiliki efek samping perdarahan dan memicu timbulnya alergi karena merupakan obat hasil dari modifikasi genetik kedelai [8]. Berdasarkan latar belakang ini maka perlu dilakukan penelitian terkait anti pembekuan darah, salah satunya dari bahan alam.

Pepaya (Carica papaya) merupakan salah satu tanaman yang banyak dijumpai di daerah tropis seperti Indonesia dan banyak dimanfaatkan oleh masyarakat sebagai obat baik itu dari daun, buah, biji, maupun getahnya. Pepaya terbukti memiliki efek farmakologis seperti antikanker [9], antimikroba dan antiinflamasi [10], analgesik [11], antioksidan [12], serta dapat menurunkan kadar gula dan lipid dalam darah [13]. Berdasarkan penelitian sebelumnya,

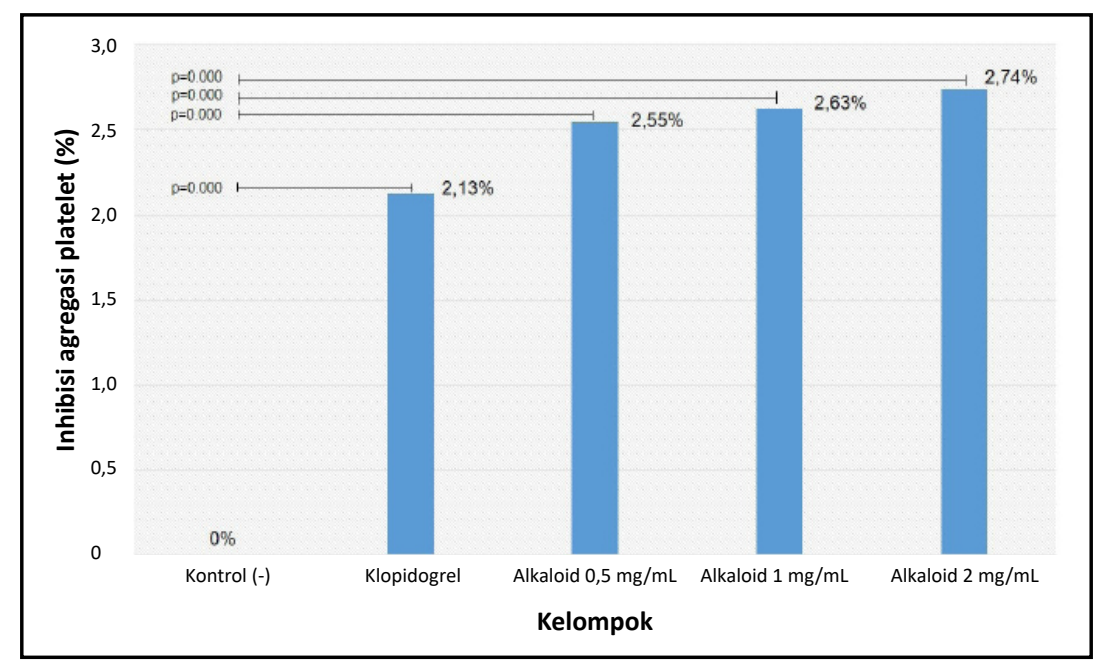

Gambar 1. Grafik uji aktivitas antiplatelet melalui inhibisi agregasi platelet. Uji one-way ANOVA menunjukkan adanya perbedaan yang signifikan antara kelompok perlakuan alkaloid total daun pepaya dengan kontrol negatif $(\mathrm{p}<0,01)$ namun tidak berbeda dengan kontrol positif $(p>0,01)$.Alkaloid total daun pepaya meningkatkan persentase inhibisi agregasi platelet (antiplatelet) 


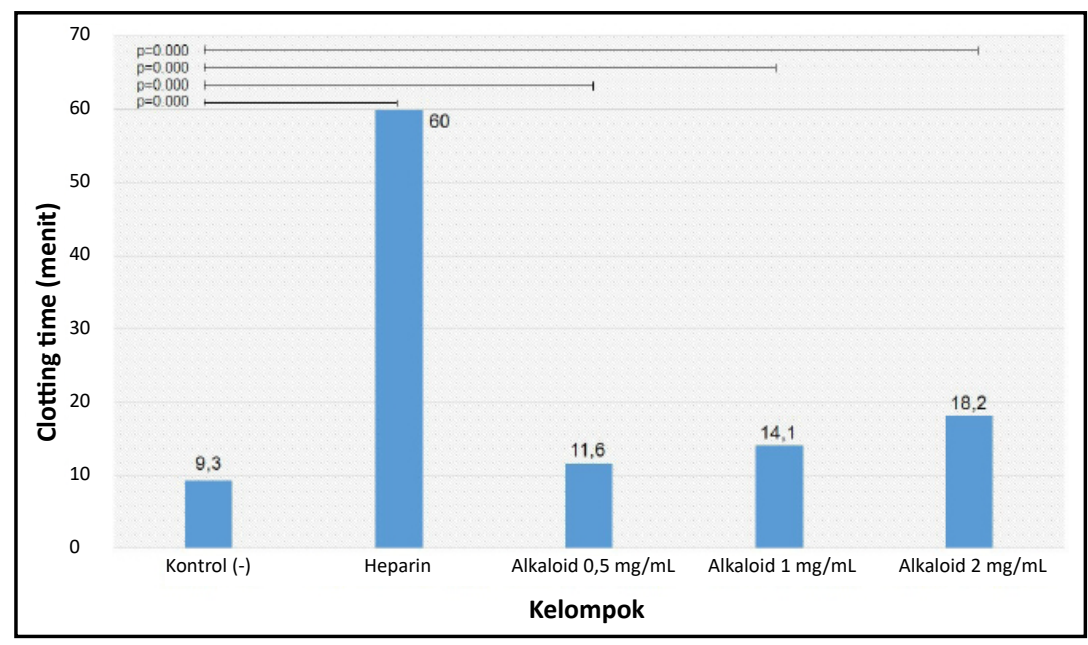

Gambar 2. Grafik uji aktivitas antikoagulan melalui pemanjangan Clotting Time (CT). Uji one-way ANOVA menunjukkan adanya perbedaan yang signifikan antara kelompok perlakuan alkaloid total daun pepaya dengan kontrol negatif $(\mathrm{p}<0,01)$ namun tidak berbeda dengan kontrol positif $(\mathrm{p}>0,01)$. Dibandingkan kontrol negatif, alkaloid total daun pepaya terbukti dapat memperpanjang nilai CT (antikoagulan).

pepaya juga memiliki aktivitas anti pembekuan darah. Getah buah pepaya terbukti memiliki aktivitas antiplatelet dan antikoagulan dibuktikan dengan peningkatan Clotting Time (CT), Prothrombine Time (PT), Activated Partial Thromboplastine Time (APTT), dan Bleeding Time (BT) secara in vitro maupun in vivo [14]. Sebagai aktivitas anti pembekuan darah, daun pepaya juga memiliki aktivitas trombolitik sebesar $23,67 \%$ secara in vitro [15]. Sejauh ini, senyawa aktif maupun mekanisme aktivitas anti pembekuan darah tanaman pepaya belum diketahui, padahal berdasarkan penelitian sebelumnya pepaya memiliki potensi sebagai anti pembekuan darah. Penelitian ini bertujuan untuk mengetahui aktivitas antiplatelet, antikoagulan, dan trombolitik dari kandungan alkaloid total daun pepaya. Alkaloid dipilih karena terbukti memiliki aktivitas antiplatelet [16,17], antikoagulan [18-20], dan trombolitik $[21,22]$.

\section{Metode Penelitian}

Bahan

Daun pepaya (Carica papaya) diperoleh dari Materia Medika Batu Malang, Indonesia. Pelarut yang digunakan yaitu etanol 96\% dan etil asetat (Emsure, Merck, Jerman), $\mathrm{NH}_{4} \mathrm{OH} 1 \mathrm{~N}$ (Emsure, Merck, Jerman), $\mathrm{H}_{2} \mathrm{SO}_{4}$ (Emsure, Merck, Jerman). Reagen pereaksi yang digunakan antara

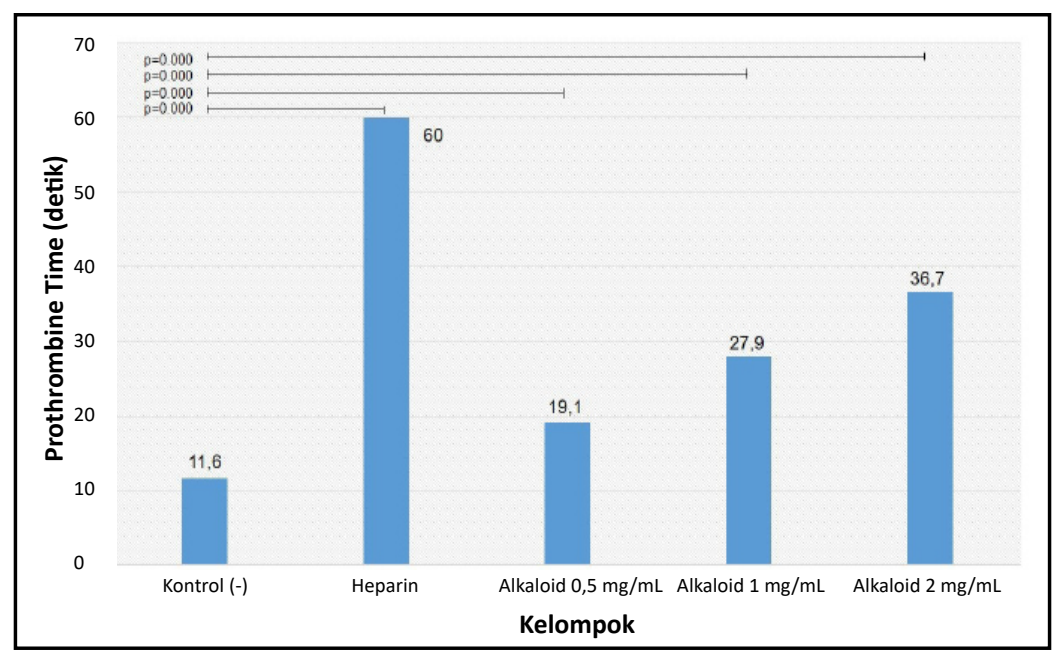

Gambar 3. Grafik uji aktivitas antikoagulan melalui pemanjangan Prothrombine Time (PT). Uji one-way ANOVA menunjukkan adanya perbedaan yang signifikan antara kelompok perlakuan alkaloid total daun pepaya dengan kontrol negatif $(p<0,01)$ namun tidak berbeda dengan kontrol positif $(p>0,01)$. Dibandingkan kontrol negatif alkaloid total daun pepaya dapat memperpanjang nilai PT (antikoagulan). 


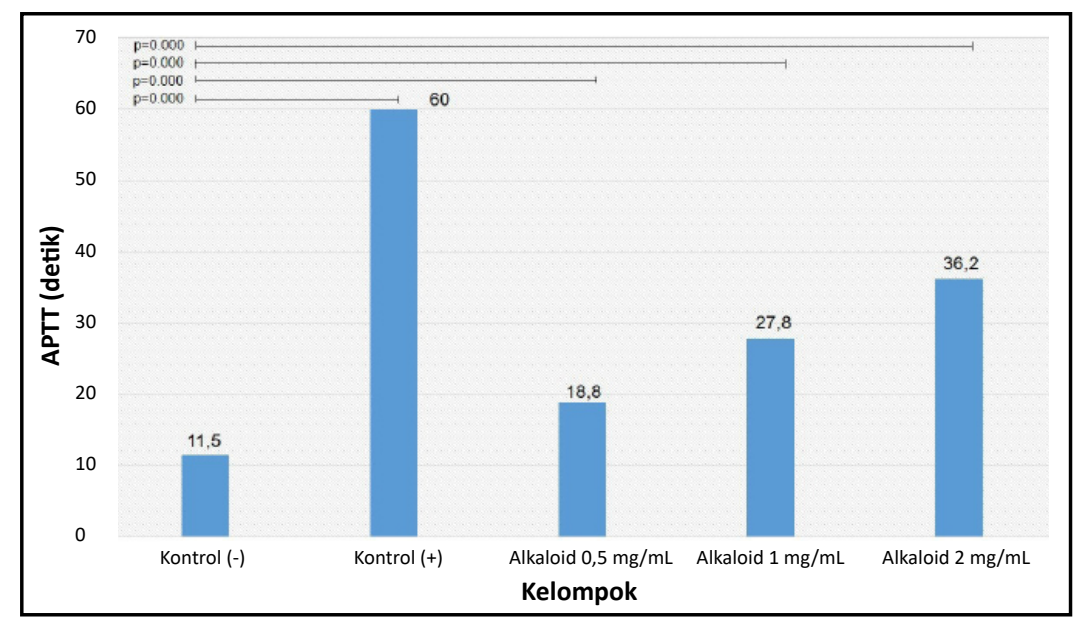

Gambar 4. Grafik uji aktivitas antikoagulan melalui pemanjangan Activated Partial Thromboplastin Time (APTT). Uji one-way ANOVA menunjukkan adanya perbedaan yang signifikan antara kelompok perlakuan alkaloid total daun pepaya dengan kontrol negatif $(p<0,01)$ namun tidak berbeda dengan kontrol positif $(p>0,01)$. Dibanding kontrol negatif, alkaloid total daun pepaya dapat memperpanjang APTT (aktikoagulan).

lain: $\mathrm{HCl} 2 \mathrm{~N}$ (Emsure, Merck, Jerman), pereaksi mayer (Nitra Kimia Indonesia), dragendorff (Emsure, Merck, Jerman), dan wagner (Nitra Kimia Indonesia), Mg (Emsure, Merck, Jerman), FeCl3 (Emsure, Merck, Jerman). Obat antipembekuan darah yang digunakan sebagai kontrol positif yaitu: klopidogrel (Dexa Medica Indonesia), heparin injeksi $5000 \mathrm{IU} / \mathrm{mL}$ (Inviclot Indonesia), nattokinase (Natto-10, Jepang). Bahan pembantu untuk melarutkan obat yaitu tween 1\% (Brataco Indonesia). Ragen yang digunakan untuk uji aktivitas adalah Adenosine Diphosphat (ADP) (Biotop Medical Belanda), reagen uji Prothrombine Time (PT) (Teclot, Rusia), dan reagen uji Activated Partial Thromboplastin Time (APTT) (Teclot, Rusia)

\section{Ekstraksi Alkaloid Total Daun Pepaya}

Sebanyak $500 \mathrm{~g}$ serbuk daun pepaya dimaserasi dengan pelarut etanol 96\% selama 24 jam sebanyak 3 kali. Filtrat hasil maserasi diuapkan pelarutnya menggunakan rotary evaporator (Rotavapor R-300, Switzerland) hingga diperoleh ekstrak kental etanol daun pepaya [23].

Ekstrak etanol ditimbang sebanyak $10 \mathrm{~g}$ kemudian dilarutkan dalam $100 \mathrm{~mL}$ etil asetat dan disaring. Residu disiapkan untuk penentuan alkaloid total. Residu dilarutkan dengan $100 \mathrm{~mL}$ etanol dan ditambahkan HCL 2 N sampai $\mathrm{pH}$ 2, kemudian dipartisi dengan $100 \mathrm{~mL}$ kloroform dan $30 \mathrm{~mL}$ air suling, selanjutnya lapisan kloroform dipisahkan. Lapisan etanol ditambahkan dengan $\mathrm{NH}_{4} \mathrm{OH} 1 \mathrm{~N}$ hingga pH 12 kemudian dipartisi lagi dengan $100 \mathrm{~mL}$ kloroform, diuapkan sehingga diperoleh ekstrak kloroform (alkaloid total) lalu dikeringkan [23].

\section{Uji Fitokimia}

Uji Fitokimia dilakukan secara kualitatif untuk melihat adanya kandungan alkaloid, flavonoid, saponin, dan tanin. Uji alkaloid dilakukan dengan menggunakan pereaksi Mayer, Dragendroff, dan Wagner. Uji flavonoid menggunakan pereaksi serbuk $\mathrm{Mg}$ dan $\mathrm{HCl}$ pekat. Uji saponin dilakukan dengan menggunakan pereaksi $\mathrm{HCl} 1$ N. Sedangkan uji tanin dilakukan dengan menggunakan pereaksi $\mathrm{FeCl}_{3}$ 10\% [24].

Persiapan Whole Blood, Platelet Rich Plasma (PRP), dan Platelet Poor Plasma

Sampel penelitian ini adalah Whole Blood, Platelet Rich Plasma (PRP), dan Platelet Poor Plasma (PPP) yang diambil dari sukarelawan dengan tekanan darah normal serta kadar glukosa dan kolesterol darah normal.

Darah vena diambil pada menggunakan spuit steril ukuran 22. Sampel darah vena dibagi ke dalam 3 grup uji: (1) Uji antikoagulan (Pengamatan CT), darah vena per sampel uji dimasukkan ke dalam 5 tabung vacuteiner masing-masing sebanyak $1 \mathrm{~mL}$; (2) Uji Fibrinolitik, darah vena dimasukkan ke dalam microtube masing-masing sebanyak $0.5 \mathrm{~mL}$; (3) Uji antiplatelet, PT dan APTT, darah vena dimasukkan ke dalam vacutainer $\mathrm{Na}$ Sitrat untuk mengambil plasma.

Penelitian ini telah mendapatkan persetujuan etik (Etchical Approval) oleh Komite Etik Penelitian Kesehatan (KEPK) RSUD Kabupaten Sidoarjo dengan nomor: 893.3/2450/438.6.7/2019. Pengambilan sampel dilakukan dengan informasi dan persetujuan subjek serta dilakukan oleh ahli teknologi laboratorium medik (ATLM) bersertifikat. 


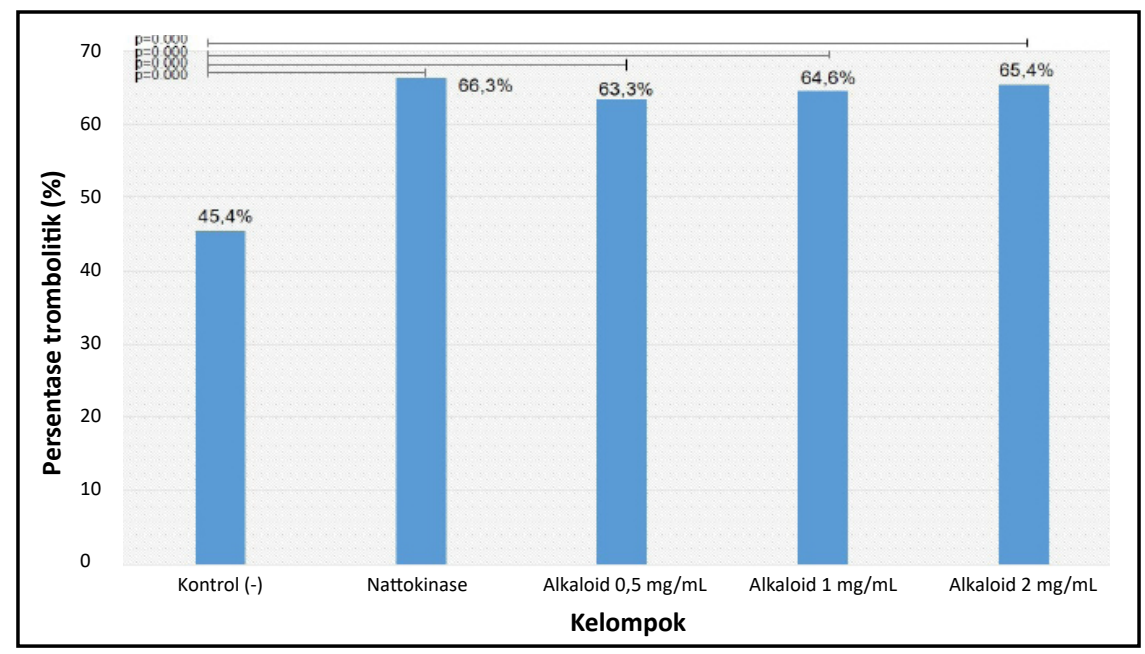

Gambar 5. Grafik uji aktivitas antikoagulan melalui peningkatan presentase trombolitik. Uji one-way ANOVA menunjukkan adanya perbedaan yang signifikan antara kelompok perlakuan alkaloid total daun pepaya dengan kontrol negatif $(\mathrm{p}<0,01)$ namun tidak berbeda dengan kontrol positif $(\mathrm{p}>0,01)$. Dibanding kontrol negatif, alkaloid daun pepaya dapat meningkatkan persentase trombolitik..

\section{Persiapan Larutan Uji}

Bahan uji pada penelitian ini terdiri dari kontrol plasebo (air suling), kontrol positif, dan ekstrak alkaloid total daun pepaya. Obat yang digunakan pada kelompok kontrol positif adalah obat yang memiliki aktivitas antiplatet (klopidogrel $0.75 \mathrm{mg} / \mathrm{mL}$, Dexa Medica Indonesia), antikoagulan (heparin $1 \mathrm{mg} / \mathrm{mL}$, Inviclot Indonesia), dan fibrinolitik (nattokinase $10 \mathrm{mg} / \mathrm{mL}$, Natto-10, Jepang) [25,26]. Ekstrak alkaloid total disuspensikan dalam air suling dengan tiga variasi konsentrasi yaitu 0,$5 ; 1$; dan 2 $\mathrm{mg} / \mathrm{mL}$.

\section{Uji Aktivitas Antiplatelet secara In Vitro}

Uji aktivitas antiplatelet secara in vitro dilakukan dengan mengamati penghambatan agregasi platelet yang terjadi saat plasma darah diberi perlakuan beserta induksi dengan Adenosine Diphosphat (ADP). Agregat platelet yang terbentuk dinilai dengan cara membandingkan serapan plasma sebelum dan sesudah diberi ADP menggunakan spektrofotometer UV Vis (Thermo Fisher Scientific, USA). Semakin besar penurunan serapan platelet plasma, maka semakin besar agregat yang terbentuk.

Platelet Rich Plasma (PRP) sebanyak $1 \mathrm{~mL}$ ditambahkan dengan larutan uji sebanyak $250 \mu$ lalu diinkubasi pada suhu $37 \%$ di dalam waterbath (Health, Korea) selama 20 menit. Setelah diinkubasi, PRP diukur serapannya menggunakan spektrofotometer UV-Vis dengan menggunakan Platelet Poor Plasma (PPP) sebagai blanko. PRP yang telah diukur serapannya kemudian ditambah dengan ADP sebanyak $20 \mu \mathrm{L}$ lalu diinkubasi di dalam waterbath pada suhu $37^{\circ} \mathrm{C}$ selama 20 menit lalu diukur serapannya kembali [25].
Persen inhibisi agregasi platelet dihitung dengan rumus berikut [27]:

$\%$ Inhibisi agregasi $=(1-\mathrm{B}) / \mathrm{A} \times 100 \%$

B: absorbansi setelah penambahan ADP

A: absorbansi sebelum penambahan ADP

Persentase (\%) inhibisi agregasi relatif terhadap kontrol negatif dihitung dengan rumus berikut:

$\%$ Inhibisi agregasi $=(\mathrm{A}-\mathrm{B}) / \mathrm{A} \times 100 \%$

A: persentase inhibisi agregasi kontrol negatif

B: persentase inhibisi agregasi perlakuan

Uji Aktivitas Antikoagulan secara In Vitro

Uji aktivitas antikoagulan secara in vitro dilakukan dengan mengamati waktu pembekuan darah/ CT dengan Metode Lee and White. Darah vena sebanyak $1 \mathrm{~mL}$ diletakkan di dalam tabung serologi berdiameter 7-8 $\mathrm{mm}$ kemudian diamati waktu pembekuan darahnya. Selain CT, uji aktivitas antikoagulan juga dilakukan dengan mengamati aktivitas jalur ekstrinsik dan intrinsik koagulasi. Uji aktivitas jalur ekstrinsik pembekuan darah melalui pengamatan masa protrombin (PT) dan Activated Partial Thromboplastine Time (APTT) [28].

\section{Uji Aktivitas Trombolitik secara In Vitro}

Setiap $500 \mu \mathrm{L}$ darah dipindahkan ke mikrotube yang telah ditimbang dengan timbangan analitik (Ohaus, Cina) terlebih dahulu. Darah kemudian dibekukan kemudian beratnya ditimbang sebagai berat bekuan awal. Setelah ditimbang, darah diinkubasi dalam inkubator (Memmert 


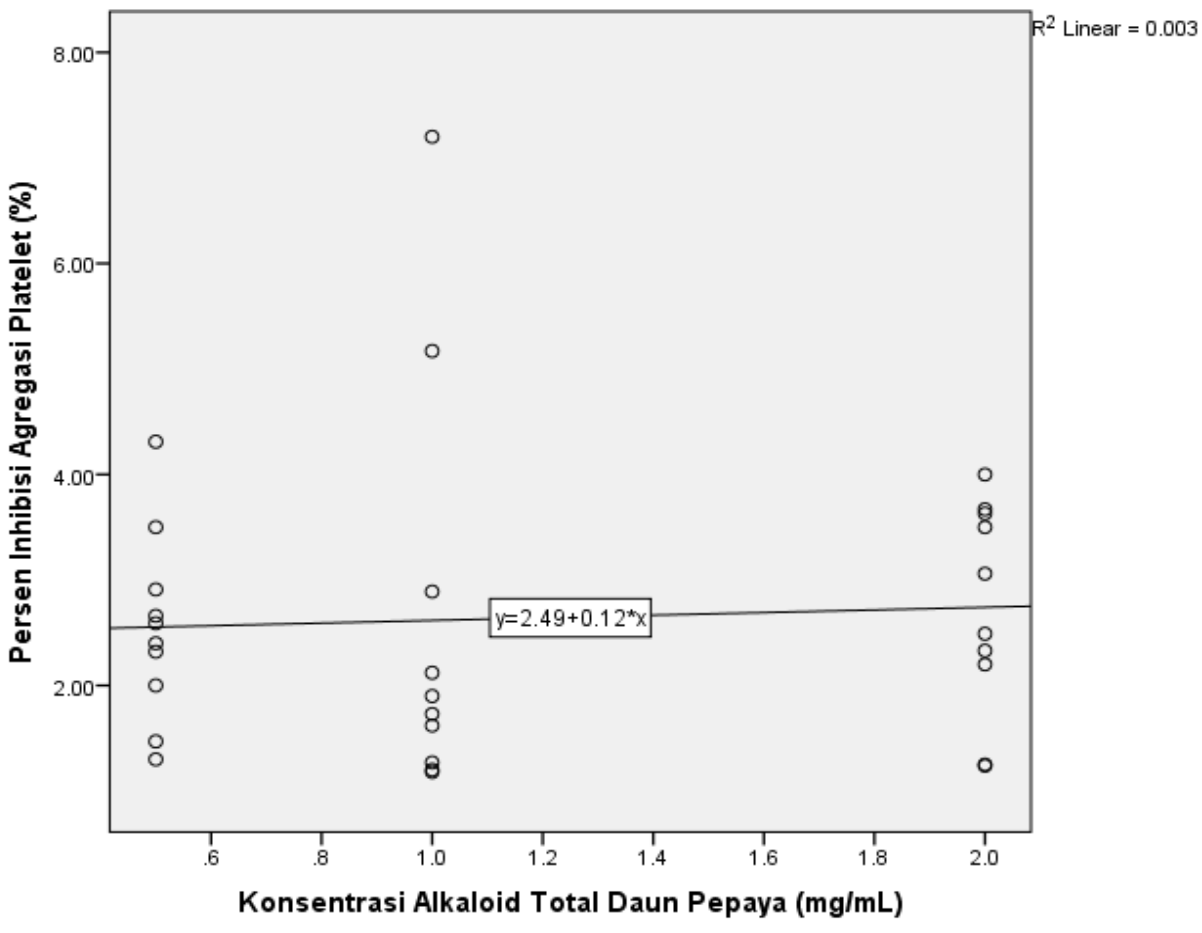

Gambar 6. Grafik korelasi konsentrasi alkaloid total daun pepaya terhadap persentase inhibisi agregasi platelet. Uji korelasi pearson menunjukkan bahwa nilai koefisien korelasi positif sebesar 0,059 dengan nilai signifikansi $\mathrm{p}=0,757$ $(p>0,01)$. Semakin tinggi konsentrasi alkaloid total daun pepaya, semakin tinggi persentase inhibisi agregasinya dengan persamaan regregsi $y=2,49+0,12 x$.

Jerman) pada suhu $37^{\circ} \mathrm{C}$ selama 60 menit setelah terbentuk bekuan. Secara langsung serum akan terperas keluar dari bekuan. Setelah 60 menit, serum diambil dari mikrotube berisi darah kemudian bekuan yang tersisa pada mikrotube ditimbang sebagai berat bekuan akhir. Persentase trombolitik dapat dihitung dari rumus berikut [29]:

$$
\% \text { Trombolitik }=(\mathrm{A}-\mathrm{B}) / \mathrm{A} \times 100 \%
$$

Keterangan = A: berat bekuan (clot) awal, B: berat bekuan (clot) akhir

\section{Analisis Data}

Data yang diperoleh berupa persentase inhibisi agregasi platelet relatif, nilai CT, nilai PT dan APTT, serta persentase trombolitik diuji normalitasnya menggunakan analisis Kolmogorof Smirnov. Data kemudian dilihat homogenisitasnya menggunakan one-way Anova (Analysis of Variance). Hubungan antar konsentrasi alkaloid total daun pepaya dianalisis menggunakan uji Korelasi Pearson dengan. Keseluruhan analisis statistik menggunakan taraf signifikansi $99 \%(\mathrm{p} \leq 0,01)$.

\section{Hasil dan Diskusi}

Ekstraksi 500 gram serbuk daun pepaya menggunakan etanol 96\% menghasilkan ekstrak kental berwarna hijau tua dengan berat 42,6 gram (8,52\%). Setelah dilakukan pemisahan, alkaloid total yang didapatkan sebanyak 0,781 gram $(1,8 \%)$. Uji fitokimia dilakukan untuk memastikan bahwa hasil ekstraksi alkaloid total daun pepaya telah didapatkan alkaloid total dan sudah terpisah dari senyawa metabolit lain. Tabel 1 menunjukkan hasil uji fitokimia ekstrak alkaloid total daun pepaya. Hasil uji fitokimia ini menunjukkan fraksi metanol masih mengandung senyawa metabolit golongan flavonoid, saponin, tanin dan alkaloid, sedangkan pada fraksi klorofom hanya terdapat senyawa golongan alkaloid.

Pemisahan alkaloid total daun pepaya menggunakan etil asetat sebagai pelarut karena etil asetat merupakan pelarut semi polar yang dapat melarutkan alkaloid yang juga memiliki sifat semi polar. Residu yang diperoleh dari pelarutan ini dilanjutkan dengan melarutkannya dalam etanol yang ditambahkan $\mathrm{HCl} 2 \mathrm{~N}$ hingga diperoleh $\mathrm{pH} 2$. $\mathrm{HCl}$ akan mengikat alkaloid dalam bentuk garam alkaloid. Pemisahan dilanjutkan dengan sistem partisi menggunakan kloroform dan air suling yang akan membentuk 2 lapisan 


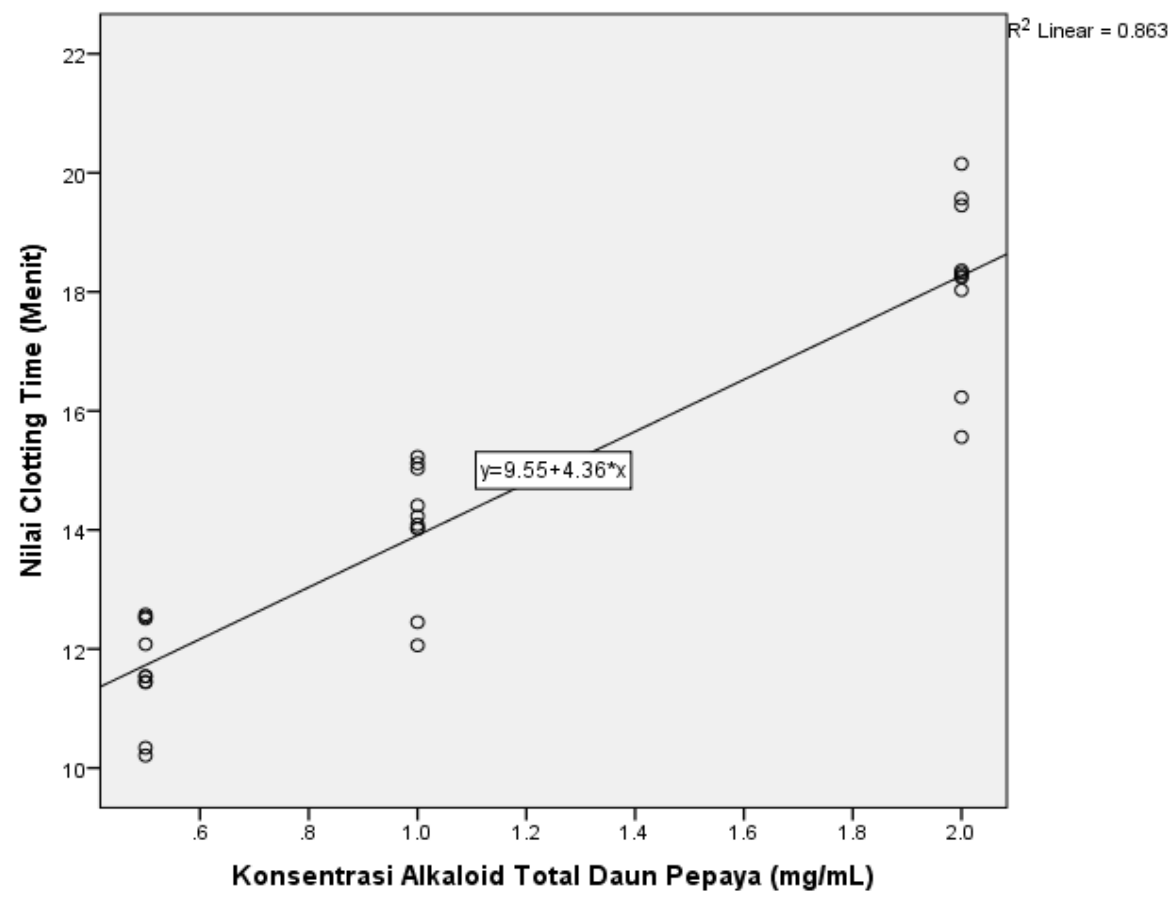

Gambar 7. Korelasi antara konsentrasi alkaloid total daun pepaya terhadap nilai Clotting Time (CT). Uji korelasi Pearson menunjukkan bahwa nilai koefisien korelasi positif sebesar 0,929 dengan nilai signifikansi $p=0,000(p<0,01)$. Semakin tinggi konsentrasi alkaloid total daun pepaya, maka semakin tinggi nilai CT dengan persamaan regregsi y=9,55 + 4,36x.

yaitu lapisan atas berupa lapisan asam yang mengandung alkaloid dan lapisan bawah berupa lapisan klorofom yang mengandung senyawa metabolit lainnya. Lapisan asam yang mengandung alkaloid ditambah dengan $\mathrm{NH}_{4} \mathrm{OH}$ yang berfungsi untuk melepaskan ikatan alkaloid dengan asam untuk membentuk alkaloid bebas. Partisi yang kedua dilakukan juga dengan pemberian klorofom untuk menangkap alkaloid bebas. Dengan demikian fraksi kloroform hanya mengandung alkaloid dan tidak mengandung senyawa metabolit lainnya [30].

Berdasarkan kajian literatur, diketahui bahwa daun pepaya mengandung alkaloid, flavonoid, fenol, asam fenolik, kolin, karposit, vitamin C dan vitamin E [31]. Pada penelitian ini, kadar alkaloid total yang diperoleh adalah 1,8\%, lebih banyak dibandingkan dengan penelitian terdahulu yang hanya memperoleh $0,2 \%$ kadar alkaloid total daun pepaya [32]. Kandungan alkaloid di dalam daun pepaya ini terdiri dari alkaloid jenis karpain, pseudokarpain, emetin dan dehidrokarpain I dan II [33]. Analisis kuantitatif karpain daun pepaya yang dimurnikan dengan HPLC menunjukkan bahwa karpain merupakan alkaloid utama dengan kandungan 63\% dari total alkaloid yang diekstrak dari daun pepaya [32].

Aktivitas antiplatelet alkaloid total daun pepaya secara in vitro diketahui dengan melihat adanya peningkatan persentase inhibisi agregasi platelet sebagaimana yang ditunjukkan dengan grafik pada Gambar 1. Hasil uji oneway Anova menunjukkan bahwa terdapat perbedaan yang signifikan antar kelompok perlakuan dengan nilai $\mathrm{F}_{\text {hit }}$ $=10,225\left(\mathrm{~F}_{\text {hit }}>\mathrm{F}_{\text {tabel }}\right)$ dan nilai signifikansi $\mathrm{p}=0,000$ $(p<0,01)$. Berdasarkan uji LSD diketahui bahwa kelompok perlakuan alkaloid total ekstrak daun pepaya berbeda signifikan dengan kontrol negatif $(p<0,01)$ namun tidak berbeda signifikan dengan kontrol positif $(p>0,01)$. Hal ini menunjukkan bahwa pemberian alkaloid total ekstrak daun pepaya memiliki aktivitas sebanding dengan kontrol positif (klopidogrel) sebagai antiplatelet. Hasil uji Korelasi Pearson menunjukkan bahwa nilai koefisien korelasi positif yaitu 0,059 dengan nilai signifikansi 0,757 ( $p>0,01)$. Hal ini menunjukkan bahwa korelasi antara peningkatan konsentrasi alkaloid total terhadap nilai persentase inhibisi agregasi platelet sangat rendah. Adanya nilai koefisien korelasi positif menunjukkan terdapat peningkatan persentase inhibisi agregasi platelet dari 0,$5 ; 1$; dan $2 \mathrm{mg} /$ $\mathrm{mL}$ dengan persamaan regresi $\mathrm{y}=2,49+0,12 \mathrm{x}$ dengan $\mathrm{R}^{2}=0,003$. Grafik analisis korelasi regresi ditunjukkan pada Gambar 6.

Aktivitas antikoagulan alkaloid total daun pepaya ditunjukkan dengan kemampuannya dalam memperpanjang CT, PT, dan APTT dibandingkan kontrol negatif. Uji 
one-way Anova menunjukkan bahwa terdapat perbedaan nilai CT, PT dan APTT yang signifikan antar kelompok perlakuan $(\mathrm{p}=0,000)$. Grafik uji aktivitas antikoagulan alkaloid total daun pepaya terhadap nilai CT, PT dan APTT ditunjukkan pada Gambar 2 , $\underline{3}$ dan $\underline{4}$. Hasil Korelasi Pearson menunjukkan bahwa nilai koefisien korelasi positif yaitu 0,929 dengan taraf signifikansi $p=0,000(p<0,01)$. Hal ini menunjukkan bahwa terdapat korelasi yang kuat antara peningkatan konsentrasi alkaloid total daun pepaya terhadap pemanjangan nilai $\mathrm{C} T$ dengan persamaan regresi $y=9,55+4,36 x$ dengan $R^{2}=0,863$. Grafik hasil uji korelasi regresi konsentrasi alkaloid total daun pepaya terhadap nilai CT ditunjukkan oleh Gambar 7. Pemberian alkaloid total daun pepaya dapat memperpanjang CT hingga 11,62 - 18,21 menit. Alkaloid total daun pepaya juga dapat memperpanjang PT hingga 19,05 - 36,69 detik dan APTT hingga 18,85 - 36,25 detik.

Aktivitas trombolitik alkaloid total daun pepaya ditunjukkan dengan kemampuannya meningkatkan lisis bekuan darah. Hasil uji one-way Anova menunjukkan adanya perbedaan persentase aktivitas trombolitik antar perlakuan $(p=0,000)$. Grafik aktivitas trombolitik alkaloid total daun pepaya ditunjukkan pada Gambar 5. Hasil uji Korelasi Pearson menunjukkan nilai koefisien korelasi positif sebesar 0,076 dengan taraf signifikansi 0,691 ( $p>0,01)$. Hal ini menunjukkan bahwa peningkatan konsentrasi alkaloid berkorelasi lemah terhadap peningkatan persentase trombolitik dengan persamaan regregasi $y=62,93+1,27 x$ dan $\mathrm{R}^{2}=0,006$. Grafik hasil uji korelasi regresi ditunjukkan oleh Gambar 8. Semakin tinggi konsentrasi alkaloid total maka semakin tinggi kemampuan trombolitik. Alkaloid total daun pepaya menyebabkan penghancuran trombus hingga $63,32-65,36 \%$.

Alkaloid pada daun pepaya terdiri dari karpain, pseudokarpain, emetin dan dehidrokarpain I dan II [32]. Sampai saat ini belum ada penelitian yang membahas mekanisme kerja alkaloid yang terkandung dalam daun pepaya sebagai antiplatelet, antikoagulan, dan trombolitik. Meskipun demikian, pendekatan fisiologis dan struktur kimia mungkin dapat diperkirakan mekanisme yang mendasari aktivitas alkaloid total daun pepaya sebagai anti pembekuan darah.

Karpain merupakan jenis alkaloid terbanyak pada daun pepaya [33]. Pada sistem kardiovaskular, karpain diketahui memiliki peranan dalam menurunkan tekanan sistolik, diastolik, dan tekanan darah arteri. Karpain juga mampu mengurangi cardiac output, stroke volume, stroke work, dan cardiac power [34]. Pada studi yang lain diketahui

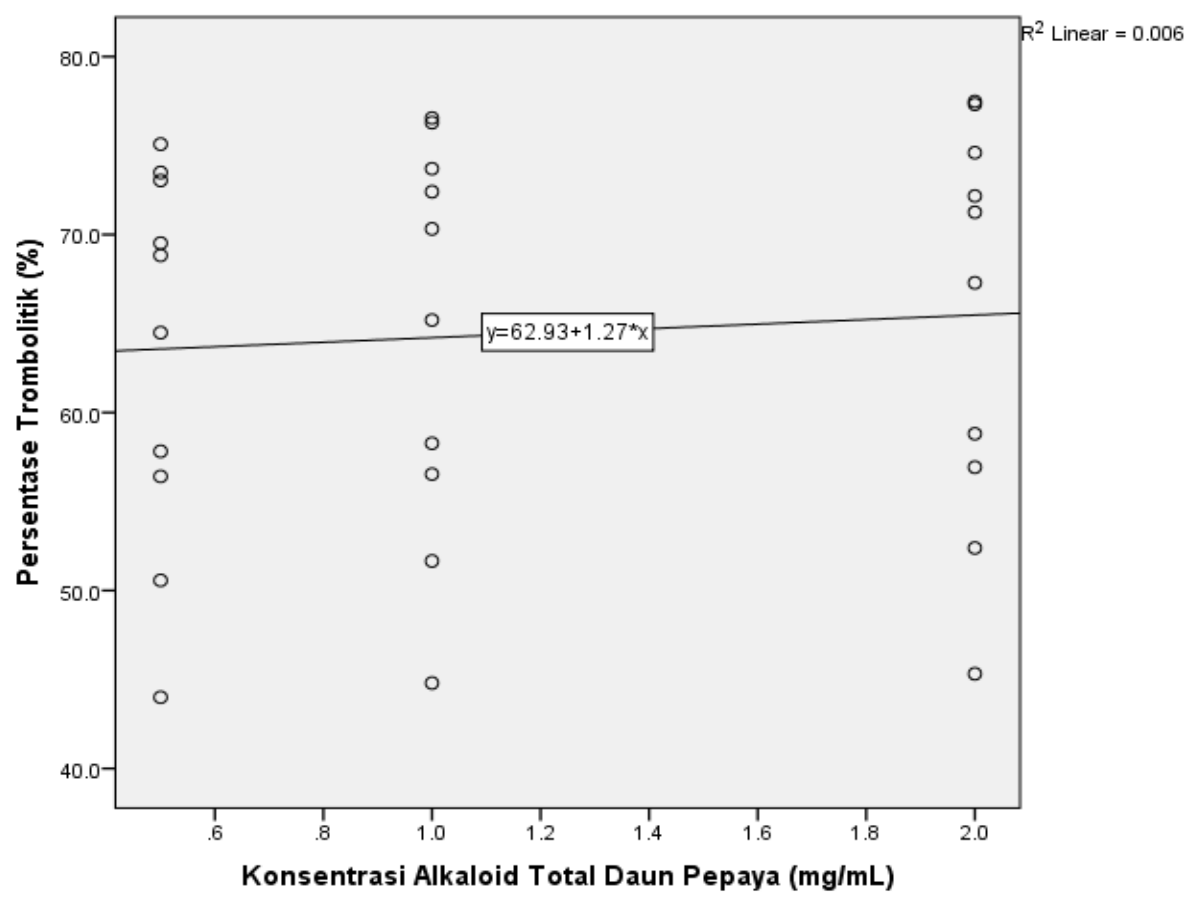

Gambar 8. Korelasi antara konsentrasi alkaloid total daun pepaya dengan persentase trombolitik. Uji korelasi Pearson menunjukkan bahwa nilai koefisien korelasi positif sebesar 0,076 dengan nilai signifikansi $p=0,691(p<0,01)$. Semakin tinggi konsentrasi alkaloid total daun pepaya, maka semakin tinggi pula persentase trombolitik dengan persamaan regresi $\mathrm{y}=62,93+1,27 \mathrm{x}$. 
bahwa karpain memiliki aktivitas antitrombositopenia yang dapat mencegah penurunkan kadar platelet dalam darah [35]. Berdasarkan penelitian tersebut, pendekatan fisiologis melalui kemampuan karpain yang dapat bekerja pada sistem kardiovaskular dan platelet memungkinkannya dapat bekerja pada proses koagulasi. Namun demikian, penelitian lebih lanjut diperlukan untuk mengetahui secara pasti mekanisme alkaloid karpain dalam menghambat pembekuan darah dan terbentuknya trombus.

Karpain $\left(\mathrm{C}_{28} \mathrm{H}_{50} \mathrm{~N}_{2} \mathrm{O}_{4}\right)$ merupakan jenis alkaloid piperidin yang terdiri dari dua cincin piperidin [36]. Derivat karpain pada daun pepaya yaitu pseudokarpain dan dehidrokarpain I dan II. Golongan alkaloid piperidin pada beberapa tanaman lain seperti piperin, piperlonguminin, dan pipernonalin terbukti memiliki aktivitas antiplatelet. Piperin merupakan jenis alkaloid piperidin yang dominan pada Piper nigrum L. secara signifikan mampu menekan produksi asam arakidonat (AA) yang kemudian menekan aktivitas tromboxan A2 (TXA2) synthase. Hal ini akan mencegah agregasi platelet sebab TXA2 merupakan sinyal biokimia yang menyebabkan agregasi platelet [37]. Piperlongumin dan pipernonalin dari Piper longum L. juga memiliki aktivitas antiplatelet melalui penghambatan asam arakidonat [38,39].

Pendekatan struktur kimia terhadap aktivitas alkaloid karpain daun pepaya juga dapat memberikan gambaran aktivitas antikoagulan. Alkaloid 4-(piperidine-1-yl) pyridine menghambat aktivitas trombin (FIIa) dan FXa pada sisi P1 sehingga dapat menurunkan koagulasi dibuktikan dengan pemanjangan APT'T [40]. Argatroban merupakan antikoagulan sintesis memiliki cincin piperidin yang dapat menghambat aktivitas koagulasi melalui inhibisi trombin (FIIa) [41].

Aktivitas trombolitik alkaloid karpain juga dapat dipelajari melalui pendekatan struktural. Berdasarkan studi in silico, seyawa piper dan piperlongumin dari Piper sylvaticum terbukti dapat menghambat tissue Plasminogen Acivator (t-PA) yang mengubah plasminogen menjadi plasmin. Plasmin merupakan enzim yang dapat memicu terjadinya trombolisis [42]. Argatroban yang memiliki cincin piperidin juga terbukti dapat menginduksi trombolisis melalui penghambatan t-PA [41].

Penelitian ini telah membuktikan adanya aktivitas antiplatelet, antikoagulan dan trombolitik alkaloid total daun pepaya (Carica papaya L.) yang dibuktikan dengan peningkatan persentase inhibisi agregasi platelet, pemanjangan CT, PT, APT'T dan peningkatan persentase trombolitik. Namun demikian, penelitian ini belum dapat membuktikan mekanisme kerja yang berperan di dalamnya. Melalui pendekatan fisiologis dan struktur molekul alkaloid karpain daun pepaya, prediksi mekanisme antiplatelet, antikoagulan dan trombolitik dapat dijelaskan. Penelitian ini berpotensi untuk dilanjutkan dengan melihat ada tidaknya aktivitas alkaloid total pada sejumlah target molekul di sistem pembekuan darah meliputi pengaruh alkaloid total pada asam arakidonat, TXA2, trombin (FIIa), FXa, dan tPA baik secara in silico, in vitro, maupun in vivo. Isolasi senyawa alkaloid karpain, pseudokarpain, dehidrokarpain I dan II serta emetin dari alkaloid total daun pepaya dan uji aktivitas anti pembekuan darahnya juga dapat dilakukan untuk mengembangkan penelitian ini. Dengan demikian maka alkaloid total daun pepaya berpotensi dapat mencegah terjadinya aterotrombotik melalui mekanime antiplatelet, antikoagulan, dan trombolitik.

\section{Kesimpulan}

Penelitian ini menunjukkan bahwa alkaloid total daun pepaya memiliki aktivitas antiplatelet, antikoagulan, dan trombolitik melalui peningkatan persentase inhibisi agregasi platelet, pemanjangan CT, PT, APTT dan peningkatan persentase trombolitik.

\section{Ucapan Terimakasih}

Ucapan terima kasih kami sampaikan kepada Kementerian Riset, Teknologi, dan Pendidikan Tinggi (KEMENRISTEKDIKTI) yang telah memberikan dukungan dana melalui hibah penelitian tahun 2018 (kontrak penelitian: 113/SP2H/LT/DRPM/2019). Ucapan terima kasih juga kami sampaikan kepada STIKES Rumah Sakit Anwar Medika yang memberikan fasilitas berupa akses referensi serta sarana dan prasarana untuk mendukung penelitian ini.

\section{Referensi}

[1] WHO. Cardiovascular Disease. WHO. 2020 [cited 13 Agustus 2020]. Available from: https://www.who.int/health-topics/ cardiovascular-diseases/\#tab=tab 1

[2] Riset Kesehatan Dasar (Riskesdas). Hasil utama Riskesdas Tahun 2018 Kementerian Kesehatan Bidang Penelitian dan Pengembangan Kesehatan. 2018 [cited 13 Agustus 2020]. Available from: https:// www.kemkes.go.id/resources/download/info-terkini/hasilriskesdas-2018.pdf

[3] Asada Y, Yamashita A, Sato Y, Hatakeyama K. Pathophysiology of atherothrombosis: mechanisms of thrombus formation on disrupted atherosclerotic plaques. Pathology International. 2020;70(4):30922. https://doi.org/10.1111/pin.12921 
[4] Angiolillo DJ, Fernandez-Ortiz A, Bernardo E, Alfonso F, Macaya C, Bass TA, Costa MA. Variability in individual responsiveness to clopidogrel. Clinical implications, management, and future perspectives. J Am Coll Cardiol. 2007;49(14):1505-16. https://doi. org/10.1016/i.jacc.2006.11.044

[5] Rodriguez, LAG, Hennekens, CH, Rothwell PM, Lanas A. Bleeding risk with long term low dose aspirin: a systematic review of observational studies. PLOS ONE. 2016;11(8):1-20. https://doi.org/10.1371/ journal.pone.0160046

[6] Altman R, Rivas AJ, Gonzales, CD. Bleeding tendency in dual antiplatelet therapy with aspirin/ clopidogrel: rescue of the template bleding time in a single-center prospective study. Thrombosis Journal. 2012;10(3):1-7. https://doi.org/10.1186/1477-9560-10-3

[7] Oduah El, Linhardt RJ, Sharfstein ST. Heparin: Past, present, and future. Pharmaceuticals. 2016;9(3):1-12. https://doi.org/10.3390/ ph9030038

[8] Weng Y, Yao J, Sparks S, Wang KY. Nattokinase: an oral antithrombotic agent for the prevention of cardiovascular disease. Int J Mol Sci 2017;18(3):523-35. https://doi.org/10.3390/ijms18030523

[9] Parray ZA, Parray S. Anticancer activities of Papaya (Carica papaya): A Review. TANG [Humanitas Medicine]. 2018;8(4):1-5. https://doi. org/10.5667/tang.2018.0020

[10] Gupta A, Patil SS, Pendharkar N. Antimicrobial and anti-inflammatory activity of aqueous extract of Carica papaya. Journal of HerbMed Pharmacology, 2017;6(4):148-52.

[11] Danborno AM, Ibrahim SH, Mallo MJ. The anti-inflammatory and analgesic effects of the aqueous leaves extract of Carica papaya. IOSR J Pharm Biol Sci. 2018;13(3):60-3. https://doi.org/10.9790/30081303046063

[12] Mandal S, De MV, Lalnunmawii E. An investigation of the antioxidant property of Carica papaya leaf extracts from mizoram, Northeast India. Research \& Reviews: Journal of Botanical Sciences. 2015;4(3):42-5.

[13] Maniyar Y, B hixavatimath, P. Antihyperglycemic and hypolipidemic activities of aqueous extract of Carica papaya linn. Leaves in alloxaninduced diabetic rats. J Ayurveda Integr Med. 2012;3(2):70-4. https://doi.org/10.4103/0975-9476.96519

[14] Asare F, Koffuor GA, Nyansah WB, Gyanfosu L, Abruquah AA. Anticoagulant and antiplatelet properties of the latex of unripe fruits of Carica papaya L. (Caricaceae). Int J Basic Clin Pharmacol. 2016;4(6):1183-88.

[15] Kalaiyarasi L, Sultana M. In vitro study of thrombolytic activity by using aqueous preparation of different parts of Carica papaya plant extract. J Pharm Biol Sci. 2014;9(30):34-9.

[16] Ain QU, Khan H, Mubarak MS, Pervaiz A. Plant alkaloids as antiplatelet agent: Drugs of the future in the light of recent developments. Front Pharmacol. 2016;7(292):1-9. https://doi.org/10.3389/ fphar.2016.00292

[17] Lee W, Lee Jl, Kulkarni R, Kim MA, Hwang JS, Na MK, et al. Antithrombotic and antiplatelet activities of small-molecule alkaloids from Scolopendra subspinipes mutilans. Sci Rep. 2016;6:112. https://doi.org/10.1038/srep21956

[18] Ku SK, Lee IC, Kim JA, Bae JS. Antithrombotic activities of pellitorine in vitro and in vivo. Fitoterapia. 2013;91:1-8. https://doi. org/10.1016/j.fitote.2013.08.004

[19] Lei L, Xue Y, Liu Z, Peng S, He Y, Zang Y. et al. Coumarin devivates from Ainsliaea fragrans and their anticoagulant activity. Sci Rep. 2014;5:19.DOi: 10.1038/srep13544
[20] Govindappa M, Naik C, Prakash B. Anticoagulant activity of partially purified coumarin (s) extracts of Sonchus oleraceus. Adv Med Plant Res. 2015;3(3):87-91.

[21] Lee Jl, Lee W, Kim MA, Hwang JS, Na MK, Bae JS. Inhibition of platelet aggregation and thrombosis by indole alkaloids isolated from the edible insect Protaetia brevitarsis seulensis (Kolbe). J Cell Mol Med. 2017;21(6):1217-27. https://doi.org/10.1111/jcmm.13055

[22] Zohoro FT, Islam SN, Khan SA, Hasan CM, Ahsan M. Antioxidant, cytotoxic, thromolytic, and antimicrobial antivity of Zanthoxylum rhetsa root bark with two isolated quinolone alkaloids. Pharmacology and Pharmacy. 2019; 10(3):137-45

[23] Irianto IDK. Formulasi Nanopartikel Pentagamavunon-0 Menggunakan Kitosan Viskositas Rendah dan Natrium Alginat dengan Metode Gelasi Ionik serta Uji Antiinflamasi secara in vivo [tesis]. Yogyakarta: Universitas Gadjah Mada; 2013.

[24] Mondong FR. Skrining fitokimia dan uji aktivitas antioksidan ekstrak etanol daun patikan emas (Euprorbia prunifolia Jacq.) dan bawang laut (Proiphys amboinensis L.) Herb). Jurnal MIPA. 2015;4(1):81-7. https://doi.org/10.35799/jm.4.1.2015.6910

[25] Lubis, ARN. Uji aktivitas in vitro antiplatelet dan antikoagulan fraksi $\mathrm{N}$-heksana kulit batang belimbing wuluh Averrhoa blimbi L.) [skipsi] Jember: Fakultas Farmasi Universitas Jember; 2015.

[26] Setyowati, R. Uji aktivitas antiplatelet dan trombolitik ekstrak etanol kulit buah jeruk purut (Citrus hystrix D.C) In Vitro. [skripsi]. Jember: Fakultas Farmasi Universitas Jember ;2015.

[27] Moriyama H, Hosoe T, Wakana D, Itabashi T, Kawai KI, lizuka T et al. Assay-guided informatory screening method for antiplatelet effect of adenosine isolated from Malbranchea filamentosa IFM 41300: Inhibitory behaviors of adenosine in different solvents. J Health Sci. 2009;55(1):103-8. https://doi.org/10.1248/jhs.55.103

[28] Gandasoebrata, R. Penuntuk Laboratorium Klinik. Jakarta: Dian Rakyat; 2007.

[29] Prasad S, Kashyap RS, Deopujari JY, Purohit HJ, Taori GM, Daginawala HF. Effect of Fagonia arabica (dhamasa) on in vitro thrombolysis. BMC Complement Altern Med. 2007;7:1-6. https://doi. org/10.1186/1472-6882-7-36

[30] Rachmanto S, Wardatun S, Miranti M. Isolasi dan penentuan aktivitas antioksidan alkaloid total daun pepaya (Carica papaya L.). [skripsi]. Bogor: FMIPA UNPAK; 2015.

[31] Julianti T, Oufir M, Hamburger M. Quantification of the antiplasmodial alkaloid carpaine in papaya (C. papaya L.) leaves. Planta Med. 2014;80(13):138-42. doi: https://doi. org/10.1055/s-0034-1382948

[32] Vien DTH, Loc TV. Extraction and quantification of carpaine from Carica papaya leaves of Vietman. Int J Agric Environ Biotechnol 2017;2(5):2394-97.

[33] Gautam G. Isolation and characterization of secondary metabolites from Carica papaya leaves. AIP Coference Proceeding. 2018;2237(1): https://doi.org/10.1063/5.0005715

[34] Hornick CA, Sandes LI, Lin YC. Effect of carpaine, a papaya alkaloid, on the circulatory function in the rat. Res Commun Chem Pathol Pharmacol. 1978; 22(2):277-89.

[35] Zunjar V, Dash RP, Jivrajani M, Trivedi B, Nivsarkar M. Antithrombocytopenic activity of carpaine and alkaloidal extract of Carica papaya Linn. leaves in busulfan induced thrombocytopenic Wistar rats. J Ethnopharmacol. 2016;181:20-5. https://doi. org/10.1016/j.jep.2016.01.035 
[36] Burdick EM. Carpain: an alkaloid of Carica papaya: Its chemistry and pharmacology. Econ Bot. 1971;25(4):363-65.

[37] Son DJ, Akiba S, Hong JT, Yun YP, Hwang SY, Park YH, et al. Piperine inhibits the activities of platelet cytosolic phospholipase $A 2$ and Thromboxane A2 Synthase without affecting cyclooxygenase-1 activity: different mechanisms of and macrofag inflammatory response. Nutrients. 2014;6(8):3336-52. https://doi.org/10.3390/ $\underline{\text { nu6083336 }}$

[38] Park BS, Son DJ, Choi WS, Takeoka GR, Han SO, Kim TW, et al. Antiplatelet activities of newly synthesized derivatives of piperlongumine. Phytother Res. 2008;22(9):1195-9. https://doi. org/10.1002/ptr.2432

[39] Park BS, Son YH, Park YH, Kim TW, Lee SE. Antiplatelet effects of acidamides isolated from the fruits of Piper longum L. Phytomedicine. 2007;14(12):853-8.
[40] Candia M, Fiorella F, Lopopolo G, Carotti A, Romano MR, et al. Synthesis and biological evaluation of direct thrombin inhibitors bearing 4-(piperidin-1-yl) pyridine at the P1 position with potent anticoagulant activity. J Med Chem. 2013;56(21):8696-711.

[41] Yamada K, Tsuji H, Kimura S, Kato H, Yano S, et al. Effects of argatroban and heparin on thrombus formation and tissue plasminogen activator-induced thrombolysis in a microvascular thrombosis model. Thrombosis Research. 2003;109:55-64.

[42] Chakrabarty N, Suez E, Shil S, Rudra P, Rumpa FT, Rahman MS, et al. In silico molecular docking of some isolated compounds of Piper sylvaticum against thrombolytic activity. J Pharmacol Clin Toxicol. 2018;6(1):1101-04.

Copyright $\odot 2020$ The author(s). You are free to share (copy and redistribute the material in any medium or format) and adapt (remix, transform, and build upon the material for any purpose, even commercially) under the following terms: Attribution - You must give appropriate credit, provide a link to the license, and indicate if changes were made. You may do so in any reasonable manner, but not in any way that suggests the licensor endorses you or your use; ShareAlike - If you remix, 